\title{
中国科学院院长郭沫若 在北京科学討論会开幕式上的欢迎詞
}

亲爱的朋友們、同志們:

1964 年北京科学討論会, 今天隆重开幕了。各位代表不辞劳苦, 远涉重洋, 从干里万 里之外来到北京参加这次討論会, 使我們感到十分高兴。我代表中国科学家和中国人民, 向 尊敬的朋友們、同志們表示最热烈的欢迎，前且表心地預祝这次会議获得成功。

今天, 在这个大厅里, 济济一堂, 坐着来自亚洲、非洲、拉丁美洲和大洋洲 43 个国家 和地区的 353 位代表。他們中間有許多是在国际科学界享有盛皆的科学家, 有許多是在各个 科学領域內卓有成就的研究工作者, 此外还有許多是科学部門和团体的領导人。他們分別向 大会提出了有关理、工、农、医、社会科学等二百多篇有价值的学术論文, 这就給这次会議 提供了极为丰富的內容。我們深信, 这次討論会一定能够成为在人类科学史上具有重大意义 的一次国际科学会議。

这次北京科学討論会所以具有特殊重大的意义, 不仅是因为会議的規模在国际科学史上 是少見的, 更重要的是因为我們四大洲的科学家成了这次会議的主人。这是一件了不起的大 事。这件事說明，在我們这些一向被帝国主义者看作不发达地区的几大洲里，获得了政治独 立的国家，在科学文化方面也取得了重要的进展。我們四大洲的人民和科学工作者已經覚醒 起来, 打破帝国主义、新老殖民主义对科学的控制和垄断, 开始把科学掌握在自己手里, 手 目决心要进一步把我們的科学文化推进到一个复兴和繁荣的新时期。这件事同时也表明, 我 們四大洲的人民和科学工作者，已經消除了由帝国主义在我們之間造成的隔関，恢复了我們 在历史上早就存在过的科学文化联系, 并且决心要在新的基础上以更大的規模来进行这方面 的合作和交流。因此, 这次科学討論会也是一次象征着我們四大洲科学家进一步团結和合作 的大会。

我們四大洲的絕大多数国家都有过共同的遭遇，长期遭受到帝国主义、新老殖民主义的 侵略和压迫，今天都还面临反对帝国主义、新老殖民主义，保卫世界和本，争取和維护民族 独立，发展独立的民族經济和民族文化的共同斗爭任务。正因为这样，在我們各国科学家之 間存在着相互了解的基础。我們在交流科学經驗、探討共同关心的問題的时候，就会格外感 到亲切，乎且容易找到对我們彼此都有好处的經驗。 
中国是一个长期遭受帝国主义祸害的国家。解放前，由于国家在政治上不独立，我們的 經济和文化也处于十分貧穷和落后的状态。我們中国老一輩的科学家都清楚地記得，在旧中 国要想从事科学研究工作有多么困难：那时候，国家存亡安危不定，人民生活在水深火热之 中，科学家处身在那样的环境，精神上苦悶傍得，生活上也沒有保障，有些人甚至連飯都吃 不飽。請問在那样的情况下, 科学家們怎么能安下心来从事科学研究呢? 就是想做点碑究工 作又有什么条件呢？只有在中华人民共和国成立以后，中国的科学家才得到了发揮自己才能 的机会, 中国的科学事业才䅞了新生。

解放后，在中国共产党和毛泽东圭席的正确領导下，在人民政府的密切关怀和大力支持 下，我国的科学事业获得了巨大的发展。我們制定了我国科学技术事业的长远发展規划。我 們充实手建立了許多不同类型的高等学校, 成立了大批的科学研究机构, 建立了科学研究基 地, 从而培养了大量的青年科学技术人員, 迅速地壮大了我国的科学技术队伍。我国广大科 学家和技术人員在各方面都得到了可靠的保障。为了使他們能够安心进行科学劳动, 政府还 为他們創造了良好的工作条件。随着我国社会主义建設事业的不断发展, 我国的科学事业正 呈現着一片无限广閵的和光明的前景。

十五年来，在我国科学工作者的积极努力下，我国的科学研究成果，无論从数量和稹量 方面来看, 都已經远远超过以往的水本。我国的科学工作者本着为人民服务、为生产服务的 精神，对国家的建設事业作出了不少的貢献。但是，我們的科学事业同我們国家和人民的需 要相比, 同二十世紀六十年代世界科学的先进水本相比, 还差得很远, 还需要我国的科学工 作者全力以赴, 迎头赶上, 我們一定要本着奋发图強, 自力更生的精神, 在各个科学領域做 出更大更多的成績。同时, 我們一定要訩真学习各国在科学技术上所取得的成果和先进經 驗。这次北京科学討論会的召开, 为我国科学界提供了一个良好的学习机会。我們一定要不 放过这次机会, 虛心地向各国科学家学习和請教。当然, 如果我們有什么經驗可以作为大家 参考的話，我們也决不客惜地把它貢献出来，手且希望能够得到大家的指教。

朋友們、同志們：我們的科学討論会負有重要的历史使命。在这次会議上，我們四大洲 的科学家，将在完全平等的基础之上，充分发揚民主协商和自由討論的精神，交流我們各国 的科学成就和經驗，探索在不同条件下发展科学和推动社会进步的道路，郑且进一步加強各 国科学家之間的团結和合作。我們坚决相信，在与会代表共同負責和一致努力下，我們的科 学討論会一定能够开好, 一定能够对发展我們各自国家的科学事业、对促进人类的幸福和进 步，作出积极的貢献。

祝北京科学討論会成功!

祝各国朋友們、同志們身体健康，工作順利! 